\title{
Pengembangan Media Pembelajaran Smart Card Perwasitan Bola Basket
}

\section{Development of Learning Media for Basketball Refereeing Smart Cards}

\author{
Tantie Rafni Permatasari ${ }^{1}$, Ayu Rizky Febriani ${ }^{2}$, Ajeng Dian Purnamasari ${ }^{3}$, Indra Jati \\ Kusuma4, Rifqi Festiawan ${ }^{5}$ \\ 1Sekolah Dasar Negeri Karang Tengah Cilongok Banyumas, Indonesia \\ 2,3,4,5Prodi Pendidikan Jasmani, Fakultas IImu-IImu Kesehatan, Universitas Jenderal Soedirma, \\ Indonesia \\ email: tantierafni@gmail.com¹ \\ do: https://doi.org/10.20884/1.paju.2020.2.1.2691
}

\begin{abstract}
Abstrak
Smart Card merupakan media pembelajaran yang efektif untuk digunakan dalam ranah pembelajaran. Smart Card sendiri dapat meningkatkan rasa keingin tahuan mahasiswa dengan suasana belajar yang lebih menyenangkan. Produk Smart Card ini akan membantu mahasiswa untuk mengerti dan memahami terkati dengan perwasitan bola basket. Metode menggunakan jenis Penelitian Research and Development $(R \& D)$, yang dilakukan dengan 10 langkah diantaranya: 1. Potensi dan masalah, 2. Pengumpulan data, 3. Desain produk, 4. Validasi desain, 5. Revisi desain, 6. Uji coba produk, 7. Revisi produk, 8. Uji coba pemakaian, 9. Revisi produk, dan 10. Produksi masal. Penelitian ini diuji cobakan pada mahasiswa Pendidikan Jasmani Universitas Jenderal Soedirman. Instrumen yang digunakan oleh peneliti adalah kuesioner pernyataan dengan menggunakan skala likert. Kemudian skor yang diperoleh diolah dan dikonversikan ke dalam kriteria penilaian produk. Hasil Penelitian menunjukan Smart Card Perwasitan Bola Basket sebagai media pembelajaran bola basket memperoleh nilai tingkat kelayakan sebesar $82,61 \%$ atau dikategorikan sangat layak, dari pada itu dapat disimpulkan bahwa Smart Card Perwasitan Bola Basket dapat digunakan sebagai media pembelajaran untuk mahasiswa Pendidikan Jasmani UNSOED. Kesimpulan dari penelitian ini yaitu Smart Card Perwasitan Bola Basket dapat diterapkan menjadi media belajar mahasiswa Pendidikan Jasmani UNSOED.
\end{abstract}

Kata Kunci : Pengembangan, Media Pembelajaran, Smart Card, Perwasitan Bola Basket

\footnotetext{
Abstract

Smart Card is an effective learning media to be used in the area of learning. Smart Card itself can increase students' curiosity with more fun learning atmosphere. This Smart Card product will help students to understand and comprehend the basketball referees. The Research and Development (R\&D) is carried out in 10 steps including: 1. Potential and problems, 2. Data collection, 3. Product design, 4. Design validation, 5. Design revisions, 6. Product trials, 7. Product revisions, 8. Application trials, 9. Product revisions, and 10. Mass production. On this study, the samples are students of Physical Education Health and Recreation at the Jenderal Soedirman University. The instrument 
used by researcher was a statement questionnaire using a Likert scale. The scores obtained are processed and converted into product evaluation criteria. Results is Basketball Refereeing Smart Card as a basketball learning media has a score of $82.61 \%$ or categorized as very feasible, therefore it can be concluded that Basketball Referees Smart Card can be used as a learning media for students of Physical Education Health and Recreation. Conclusion from this study is basketball refereeing smart card can be applied as a learning media for student of physical education healt and recreation at Jenderal Soedirman Univercity.

Keywords : Development, Learning Media, Smart Card, Basketball Referees

\section{PENDAHULUAN}

Bola basket merupakan salah satu mata kuliah yang diajarkan pada Program Studi Pendidikan Jasmani di Fakultas IImu-IImu Kesehatan Universitas Jenderal Soedirman sebagai salah satu kompetensi yang harus dimiliki oleh mahasiswa olahraga. Permainan bola basket merupakan suatu perpaduan antara bagaimana caranya bertahan dan bagaimana menyerang dengan menggunakan berbagai teknik passing, dribbling dan shooting yang didasari oleh peraturan permainan (Agustan, Kusmaedi, \& Hendrayana, 2020). Pembelajaran bola basket di perguruan tinggi memiliki karakteristik yang berbeda dengan pembelajaran di sekolah menengah (Sampurno \& Qohhar, 2020). Mahasiswa Program Studi Pendidikan Jasmani di Fakultas IImu-Imu Kesehatan Universitas Jenderal Soedirman harus dapat melakukan berbagai teknik dasar bola basket pada mata kuliah bola basket I dan pada pada materi bola basket II diharapkan mahasiswa dapat melakukan berbagai keterampilan bermain serta memahami pertandingan dan perwasitan bola basket

Mata Kuliah Metodik Didaktik Bola Basket II merupakan lanjutan dari materi Bola Basket I dan merupakan salah satu mata kuliah yang terdapat pada Program Studi Pendidikan Jasmani Fakultas IImu-IImu Kesehatan Universitas Jenderal Soedirman. Pada mata kuliah Metodik Didaktik bola basket II terdapat materi perwasitan yang wajib dilalui oleh tiap-tiap mahasiswa. Berdasarkan hasil observasi peneliti di Pendidikan Jasmani Universitas Jenderal Soedirman angkatan 2016, dari 39 mahasiswa yang mengambil mata kuliah Metodik Didaktik Bola Basket II terdapat 16 mahasiswa yang mendapatkan nilai di bawah "D" dengan klasifikasi nilai 46 s.d 55 terkait dengan materi perwasitan bola basket. Hasil dari wawancara kepada beberapa mahasiswa menyatakan mengalami kesulitan untuk memahami dan mengerti istilah yang digunakan dalam perwasitan bola basket yang menggunakan bahasa asing. Materi perwasitan sendiri merupakan materi yang harus 
Tantie Rafni Permatasari, Ayu Rizky Febriani, Ajeng Dian Purnamasari, Indra Jati Kusuma, Rifqi Festiawan | Pengembangan Media Pembelajaran Smart Card Perwasitan Bola Basket

dikuasai oleh mahasiswa agar mahasiswa bisa menempuh atau lulus dari mata kuliah Metodik Didaktik Bola Basket II.

Mata Kuliah Metodik Didaktik bola basket II mahasiswa harus mampu berperan sebagai seorang wasit yang bertugas untuk memimpin jalannya pertandingan. Dalam FIBA (2018) wasit akan terdiri dari seorang crew chief dan 1 atau 2 umpire, mereka akan dibantu oleh petugas meja dan seorang commissioner, jika hadir. Wasit mempunyai wewenang dalam membuat keputusan pada saat violation (pelanggaran terhadap peraturan) atau foul (pelanggaran atas persinggungan). Permasalahan yang terjadi sehingga menyebabkan tingkat pemahaman mahasiswa yang cukup rendah mengenai perwasitan dalam bola basket yaitu karena tidak semua mahasiswa memahami bagaimana tugas seorang wasit dalam memimpin pertandingan bola basket, hal ini dikarenakan mahasiwa yang mengikuti perkuliahan bola basket II dengan menekankan materi kepada perwasitan buka semuanya atlet atau pemain basket.

Berdasarkan latar belakang di atas, alternatif pembelajaran sangat perlu diterapkan dalam pembelajaran sehingga dapat membantu mahasiswa untuk mengerti akan materi perwasitan bola basket. Maka dari itu peneliti berupaya untuk membuat sebuah media pembelajaran perwasitan bola basket.. Media pembelajaran yang didalamnya mengandung unsur modifikasi dan inovasi merupakan salah satu cara terbaik untuk meningkatkan efektivitas pembelajaran (Budi, 2015).

Media pembelajaran sangatlah berguna untuk menarik perhatian dan juga motivasi mahasiswa pada saat proses belajar berlangsung. Media juga berguna sebagai sebuah rangsangan motivasi mahasiswa untuk mengikut pembelajaran dan memberikan sebuah pengalaman yang menyeluruh sehingga mahasiswa mendapatkan pembelajaran mandiri (Febriani, Hidayat, \& Budi, 2019). Banyak sekali media pembelajaran yang dapat dipergunakan oleh mahasiswa, salah satunya adalah Smart Card.

Kata "Smart Card" berasal dari bahasa inggris yang berarti kartu pintar. Kartu pintar merupakan alat bermian bagi anak-anak yang membuat anak menjadi kreatif dan inovatif (Yuslolita, 2019). Menurut Faridah (2019) kartu pintar atau Smart Card merupakan benda visual yang terdapat sebuah informasi yang hendak disampaikan. Smart Card sendiri terbukti dapat mengubah suasana belajar lebih menyenangkan, meningkatkan antusias dari peserta didik dan tentunya dapat menarik perhatian dari peserta didik. Smart 
Card sendiri merupakan media pembelajaran yang sangat efektif untuk digunakan dalam ranah pembelajaran (Oktaviani, Sudrajat, \& Wijayanti, 2019).

Penelitian ini penting untuk dilakukan karena, dengan mengembangkan media atau alat bantu pembelajaran perwasitan kepada mahasiswa maka diharapkan proses pengenalan dan pemahaman mahasiswa dalam berbagai teknik perwasitan bola basket dapat meningkat, selain itu penggunaan media Smart Card sebagai alat bantu pembelajaran masih jarang dilakukan dan bahwan di Prodi Pendidikan Jamani Fakultas IImu-IImu Kesehatan Unsoed belum pernah dilakukan kajian mengenai penggunaan media semart card sebagai upaya meningkatkan pemahaman dan kinerja perwasitan bola basket pada mahasiswa.

Tujuan dari penelitian ini yaitu untuk mengetahui apakah Smart Card perwasitan bola basket dapat diterapkan sebagai media belajar perwasitan bola basket untuk mahasiswa Pendidikan Jasmani UNSOED. Smart Card ini dapat menjadi salah satu media yang dapat dipilih mahasiswa untuk memudahkan pemahaman terkait perwasitan bola basket.

\section{METODE}

Penelitian ini adalah Penelitian dan Pengembangan (Research and Development) menurut (Sugiyono, 2016) dengan langkah-langkah sebagai berikut: (1) Potensi dan Masalah, (2) Pengumpulan Data, (3) Desain Produk, (4) Validasi Desain, (5) Revisi Desain, (6) Uji coba Produk, (7) Revisi Produk, (8) Uji coba Pemakaian, (9) Revisi produk, (10) Produksi Massal.

Peneliti menggunakan mahasiswa Pendidikan Jasmani UNSOED sebagai sampel penelitian, yang mana 20 mahasiswa sebagai sampel uji coba produk (skala kecil) dan 34 mahasiswa sebagai sampel uji coba pemakaian (skala besar). Untuk validator peneliti menyiapkan 3 ahli sesuai dengan bidang yang dibutuhkan yaitu: ahli materi, ahli bahasa, dan ahli media. Waktu penelitian dilaksanakan selama 2 hari yaitu pada tanggal 20 dan 21 November 2019 di Gedung Pendidikan Jamani UNSOED.

Untuk analisi data peneliti menggunakan data kuantitatif yang berupa penilaian, dihimpun melalui kuesioner atau angket uji coba produk, saat kegiatan uji coba berlangsung, dianalisis dengan analisis kuantitatif deskriptif. Persentase dimaksudkan 
Tantie Rafni Permatasari, Ayu Rizky Febriani, Ajeng Dian Purnamasari, Indra Jati Kusuma, Rifqi Festiawan | Pengembangan Media Pembelajaran Smart Card Perwasitan Bola Basket

untuk mengetahui status sesuatu yang dipersentasekan dan disajikan tetap berupa persentase. Penyusunan kuesioner menggunakan skala likert dengan bentuk jawaban "sangat baik", "baik", "cukup", "kurang", "sangat kurang" dan untuk keperluan analisis kuantitatif maka jawaban itu dapat diberi skor sebagai berikut (Mózo, 2017).
1. Sangat baik diberi
skor 5
2. Baik diberi
skor 4
3. Cukup diberi skor 3
4. Kurang diberi skor 2
5. Sangat kurang diberi skor 1

Berdasarkan jumlah pendapat atau jawaban tersebut, peneliti mempersentasekan masing-masing hasil jawaban dengan rumus (Saftari, 2019):

$$
\mathrm{P}=\frac{\text { Jumlah skor yang diperoleh }}{\text { jumlah skor maksimal }} \times 100 \%
$$

Keterangan:

$\mathrm{P}=$ Persentase kelayakan skor yang diperoleh

Setelah diperoleh hasil dengan rumus tersebut, selanjutnya kelayakan media pembelajaran Smart Card perwasitan bola basket dalam penelitian pengembangan ini digolongkan ke dalam empat kategori kelayakan (Festiawan \& Arovah, 2020), seperti tertera pada tabel 1 di bawah ini.

Tabel 1. Kategori Persentase Kelayakan

\begin{tabular}{lll}
\hline No & Skor $(\%)$ & Kategori kelayakan \\
\hline 1 & $0-20$ & Sangat Kurang \\
\hline 2 & $21-40$ & Kurang \\
\hline 3 & $41-60$ & Cukup \\
\hline 4 & $61-80$ & Baik \\
\hline 5 & $81-100$ & Sangat Baik \\
\hline
\end{tabular}

\section{HASIL}

Penelitian dan Pengembangan (Research and Development) menurut (Sugiyono, 2016) dengan langkah-langkah sebagai berikut: 


\section{Desain Produk}

Desain awal produk adalah media yang berbentuk kartu sejumlah 46 buah dengan ukuran 7 X $10 \mathrm{~cm}$. Warna Smart Card sisi depan berwarna biru dan terdapat gambar wasit yang menunjukkan materi perwasitan dan sisi belakang Smart Card berisikan penjelasan. Desain akhir produk Smart Card Perwasitan Bola Basket dibedakan menjadi 6 warna sesuai dengan materi yang dijabarkan, hijau untuk sinyal pertandingan, tosca untuk violation, orange untuk foul penalty administration reporting table, salem untuk administrating free throws-passive official, ungu untuk nomor punggung dan merah untuk foul. Smart Card yang berjumlah 46 kartu ditambahkan sesuai dengan saran ahli materi menjadi 60 kartu Smart Card.

\section{Validasi Tahap Satu}

a. Hasil Validasi Ahli Materi

Ahli materi yang digunakan oleh peneliti adalah seorang wasit bola basket berlisensi B2 yang bernama Trisna Indra Saputra. Data yang diperoleh dalam penelitian ini adalah dengan cara memberikan kisi-kisi materi yang hendak dijadikan produk disertai dengan butir pernyataan yang berupa angket. Data hasil dari validasi ahli materi dapat dilihat pada tabel 2 berikut:

Tabel 2. Data Hasil Validasi Ahli Materi Tahap Ke-1

\begin{tabular}{llllll}
\hline No & $\begin{array}{l}\text { Aspek yang } \\
\text { dinilai }\end{array}$ & $\begin{array}{l}\text { Skor yang } \\
\text { diperoleh }\end{array}$ & $\begin{array}{l}\text { Skor } \\
\max \end{array}$ & Persentase & Kategori \\
\hline 1 & $\begin{array}{l}\text { Kelayakan } \\
\text { materi }\end{array}$ & 40 & 50 & $80 \%$ & Baik \\
& & & & & \\
\hline
\end{tabular}

Berdasarkan tabel 4.3, data nilai yang diperoleh dari validasi ahli materi sebanyak 40 dari skor maksimal 50, maka persentase nilai yang didapatkan adalah (40:50) $\times 100 \%=80 \%$ dikategorikan baik sesuai dengan tabel 3 Pada validasi tahap satu ahli materi memberikan penambahan materi sebagai berikut:

Tabel 3. Revisi Ahli Materi Tahap Ke-1

\begin{tabular}{ll}
\hline No & \multicolumn{1}{c}{ Penambahan Materi } \\
\hline 1 & Materi sinyal pertandingan diantaranya: start the clock, satu angka, dua angka, \\
& tiga angka dan media time out. \\
\hline 2 & $\begin{array}{l}\text { Materi foul diantaranya: foul on act of shooting, foul not on the act of shooting, } \\
\text { dan fake a foul. }\end{array}$ \\
\hline 3 & Materi foul penalty administration reporting table diantaranya: one free throw, \\
\hline
\end{tabular}


Tantie Rafni Permatasari, Ayu Rizky Febriani, Ajeng Dian Purnamasari, Indra Jati Kusuma, Rifqi Festiawan | Pengembangan Media Pembelajaran Smart Card Perwasitan Bola Basket

\begin{tabular}{ll}
\hline & two free throw, three free throw. \\
\hline $4 \quad$ Materi nomor punggung diantaranya: 38,62, dan 78. \\
\hline
\end{tabular}

b. Hasil Validasi Ahli Bahasa

Ahli bahasa yang digunakan oleh peneliti merupakan dosen pendidikan bahasa inggris Fakultas IImu Budaya Universitas Jenderal Soedirman. Data yang diperoleh dalam penelitian ini adalah dengan cara memberikan materi dan juga penjelasan yang disertai dengan angket atau butir pernyataan. Data hasil dari validasi ahli Bahasa dapat dilihat pada tabel 4 berikut:

Tabel 4. Data Hasil Validasi Ahli Bahasa Tahap Ke-1

\begin{tabular}{llllll}
\hline No & Aspek yang dinilai & $\begin{array}{l}\text { Skor yang } \\
\text { diperoleh }\end{array}$ & $\begin{array}{l}\text { Skor } \\
\max \end{array}$ & Persentase & Kategori \\
\hline 1 & Bahasa & 33 & 50 & $66 \%$ & Baik
\end{tabular}

Pada tabel 4.5, nilai yang diperoleh untuk kebahasaan Smart Card perwasitan bola basket sebesar 33 dari skor maksimal 50, maka dapat dilihat persentase $=(33: 50) \times 100 \%=66 \%$ dikategorikan Baik. Ahli bahasa memberikan perbaikan seperti pada tabel 5 sebagai berikut:

Tabel 5. Revisi Ahli Bahasa Tahap Ke-1

\begin{tabular}{lll}
\hline No & \multicolumn{2}{c}{ Perbaikan Kata } \\
\cline { 2 - 3 } & Awal & Akhir \\
\hline 1 & Pemberhentian & Penghentian \\
\hline 2 & Menjulurkan & Mengangkat \\
\hline
\end{tabular}

c. Hasil Validasi Ahli Media

Ahli media yang digunakan oleh peneliti adalah karyawan bidang IT di Rumah Sakit Umum Daerah (RSUD) Banyumas. Data yang diperoleh dalam penelitian ini adalah dengan cara memberikan desain yang sudah peneliti rancang sebelumnya. Data hasil dari validasi ahli Media dapat dilihat pada tabel 6 dibawah ini:

Tabel 6. Data Hasil Validasi Ahli Media Tahap Ke-1

\begin{tabular}{llllll}
\hline No & Aspek yang dinilai & $\begin{array}{c}\text { Skor yang } \\
\text { diperoleh }\end{array}$ & $\begin{array}{l}\text { Skor } \\
\text { max }\end{array}$ & Persentase & Kategori \\
\hline 1 & Desain Smart Card Perwasitan Bola Basket & 30 & 50 & $60 \%$ & Cukup
\end{tabular}


Berdasarkan tabel 4.7, nilai yang diperoleh untuk desain Smart Card perwasitan bola basket sebesar 30 dari skor maksimal 50, maka dapat dilihat persentase $=(30: 50) \times 100 \%=60 \%$ dikategorikan cukup. Perbaikan ataupun penambahan diberikan oleh ahli media seperti tertera pada tabel 7 sebagai berikut:

Tabel 7. Revisi Ahli Media Tahap Ke-1

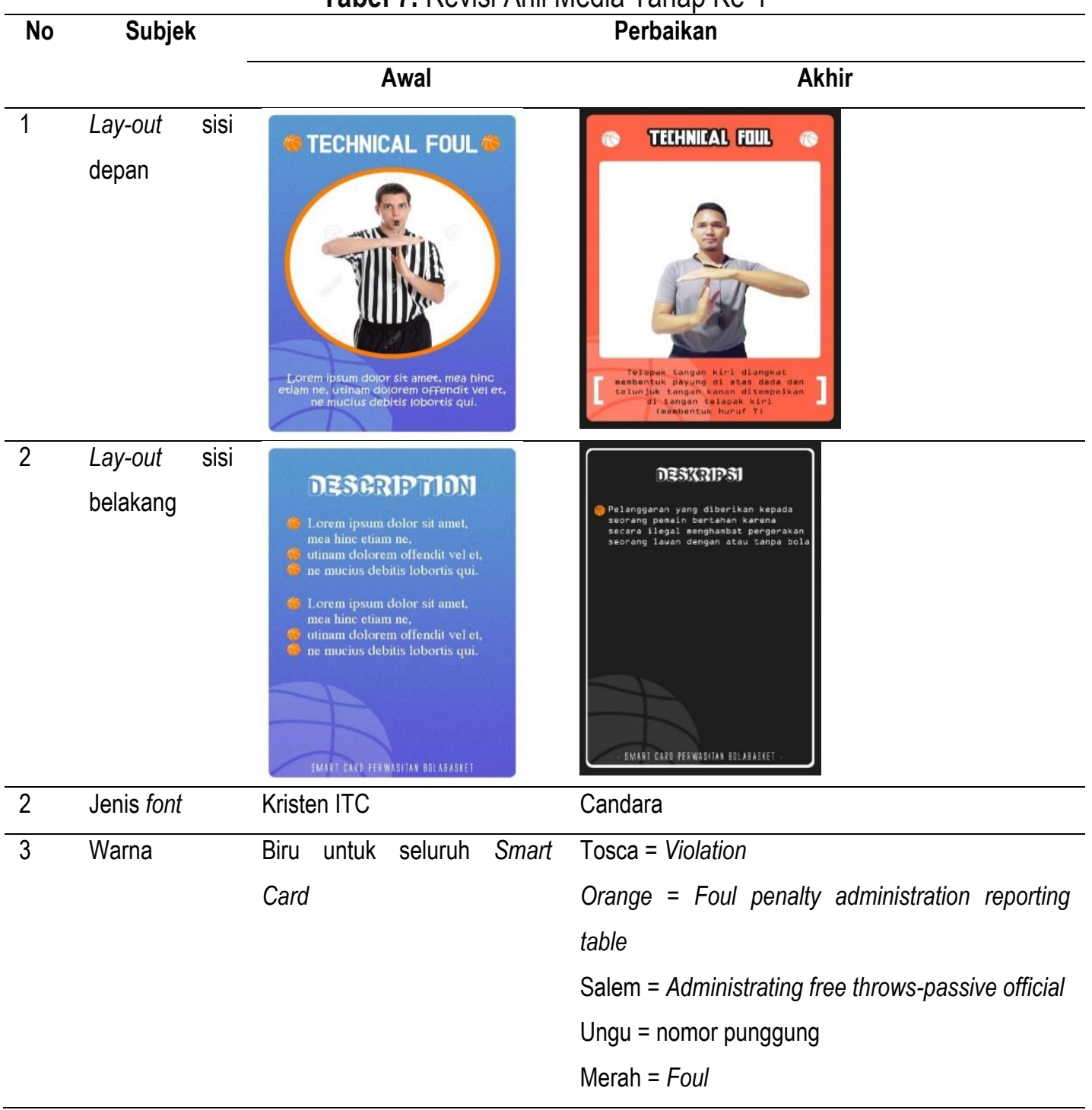

3. Validasi Tahap dua

a. Revisi Produk Berdasarkan Saran dari Ahli Materi

Data hasil dari validasi ahli materi tahap kedua dapat dilihat pada tabel 8 berikut:

Tabel 8. Data Hasil Validasi Ahli Materi Tahap Ke-2

\begin{tabular}{llllll}
\hline No & Aspek yang dinilai & $\begin{array}{l}\text { Skor yang } \\
\text { diperoleh }\end{array}$ & $\begin{array}{l}\text { Skor } \\
\max \end{array}$ & Persentase & Kategori \\
\hline 1 & Kelayakan materi & 42 & 50 & $84 \%$ & Sangat Baik
\end{tabular}


Tantie Rafni Permatasari, Ayu Rizky Febriani, Ajeng Dian Purnamasari, Indra Jati Kusuma, Rifqi Festiawan | Pengembangan Media Pembelajaran Smart Card Perwasitan Bola Basket

Berdasarkan tabel di atas, nilai yang diperoleh dari segi kelayakan isi adalah sebesar 42 dari skor maksimal 50, maka persentase yang diperoleh (42:50) x 100\% $=84 \%$ dikategorikan sangat baik.

b. Revisi Produk Berdasarkan Saran dari Ahli Bahasa

Data hasil dari validasi ahli bahasa tahap kedua dapat dilihat pada tabel 9 berikut:

Tabel 9. Data Hasil Validasi Ahli Bahasa Tahap Ke-2

\begin{tabular}{llllll}
\hline No & Aspek yang dinilai & $\begin{array}{l}\text { Skor yang } \\
\text { diperoleh }\end{array}$ & $\begin{array}{l}\text { Skor } \\
\max \end{array}$ & Persentase & Kategori \\
\hline 1 & Kebahasaan & 38 & 50 & $76 \%$ & Baik
\end{tabular}

Pada tabel di atas maka, nilai yang diperoleh dari segi kelayakan bahasa adalah sebesar 38 dari skor maksimal 50, maka persentase yang diperoleh (38:50) x $100 \%=76 \%$ dikategorikan baik.

c. Revisi Produk Berdasarkan Saran dari Ahli Media

Data hasil dari validasi ahli media tahap kedua dapat dilihat pada tabel 10 berikut:

Tabel 10 Data Hasil Validasi Ahli Media Tahap Ke-2

\begin{tabular}{|c|c|c|c|c|c|}
\hline No & Aspek yang dinilai & $\begin{array}{l}\text { Skor yang } \\
\text { diperoleh }\end{array}$ & $\begin{array}{l}\text { Skor } \\
\max \end{array}$ & Persentase & Kategori \\
\hline 1 & $\begin{array}{ll}\text { Desain Smart } & \text { Card } \\
\text { Perwasitan } & \text { Bola } \\
\text { Basket } & \end{array}$ & 40 & 50 & $80 \%$ & Baik \\
\hline
\end{tabular}

Tabel di atas, menunjukkan bahwa nilai yang diperoleh dari segi kelayakan desain sebesar 40 dari skor maksimal 50 , maka persentase yang diperoleh $(40: 50) \mathrm{x}$ $100 \%=80 \%$ dikategorikan baik.

(Festiawan, Ngadiman, Kusuma, Nurcahyo, \& Kusnandar, 2019) menyatakan bahwa sebelum pelaksanaan uji coba para ahli hendaklah menilai bahwa suatu media pembelajaran telah sesuai dengan unsur-unsur penilaian. Nilai yang didapat dari para ahli akan menjadi acuan kelayakan sebuah media pembelajaran yang siap untuk diujicobakan. Untuk uji validasi kelayakan produk tahap 1 dapat dilihat pada lampiran V dan untuk uji validasi kelayakan produk tahap 2 dapat dilihat pada lampiran VII. Untuk uji validasi kelayakan produk tahap 1 dapat dilihat pada lampiran $V$ dan untuk uji validasi kelayakan produk tahap 2 dapat dilihat pada lampiran VII. 


\section{Uji Coba Produk / Uji Coba Skala Kecil}

Uji coba produk terbagi atas uji coba produk/ skala kecil dan uji coba pemakaian/ skala besar. Untuk uji coba produk/ skala kecil peneliti mengujikan kepada 20 mahasiswa Pendidikan Jasmani Universitas Jenderal Soedirman angkatan 2017 untuk menilai kelayakan Smart Card Perwasitan Bola Basket. Proses pelaksanaan untuk menilai kelayakan Smart Card Perwasitan Bola Basket dengan cara mahasiswa dikelompokkan menjadi kelompok kecil yang beranggotakan 2 - 3 orang. Peneliti kemudian memberikan waktu kurang lebih 5 menit untuk mahasiswa terlebih dahulu melihat bentuk dari Smart Card Perwasitan Bola Basket.

Setelah mahasiswa melihat bentuk dari Smart Card Perwasitan Bola Basket selanjutnya peneliti mengarahkan untuk melihat satu-persatu sesuai instruksi peneliti, mahasiswa dapat bebas untuk bertanya ketika sesi diskusi. Mahasiswa dapat memberikan respon terkait dengan Smart Card Perwasitan Bola Basket melalui kuesioner yang sudah disediakan oleh peneliti. Data kuesioner yang telah diisi oleh mahasiswa kemudian diolah sehingga memperoleh hasil akhir dalam bentuk persentase dan akan dikategorikan sesuai dengan norma yang sudah ada.

Nilai yang diperoleh pada uji coba skala kecil akan dijadikan sebagai pedoman untuk revisi produk. Nilai hasil revisi yang didapatkan terlebih dahulu dikonsultasikan kepada para ahli kemudian diuji coba pada skala besar. Data yang diperoleh dalam uji coba skala kecil berupa skor dan saran. Untuk skala kecil diperoleh skor sebesar 1703 dari skor maksimal 2000, kemudian dikonversikan sebagai berikut:

$$
\begin{aligned}
& \mathrm{P}=\frac{\begin{array}{l}
\text { Jumlah skor yang } \\
\text { diperoleh }
\end{array}}{\text { jumlah skor maksimal }} \times 100 \% \\
& \mathrm{P}=\frac{1703}{2000} \times 100 \% \\
& \mathrm{P}=85,15 \%
\end{aligned}
$$

Pada uji coba skala kecil memperoleh penilaian sebesar $85,15 \%$ yang dikategorikan baik. Nilai uji coba produk skala kecil dapat dilihat pada lampiran VIII.

\section{Revisi Produk}

Pada skala kecil beberapa mahasiswa memberikan komentar terkait dengan ukuran tulisan pada Smart Card yang dinyatakan terlalu kecil sehingga sulit untuk dibaca. Peneliti merevisi produk berdasarkan hasil konsultasi kepada para ahli, apabila para ahli 
Tantie Rafni Permatasari, Ayu Rizky Febriani, Ajeng Dian Purnamasari, Indra Jati Kusuma, Rifqi Festiawan | Pengembangan Media Pembelajaran Smart Card Perwasitan Bola Basket

menyatakan untuk direvisi maka peneliti akan merevisi dan apabila para ahli menyatakan tidak harus direvisi maka peneliti tidak akan merevisi. pada permasalahan tersebut ahli media menyatakan untuk tidak direvisi dikarenakan ukuran tulisan sudah sesuai dengan ukuran kartu yang digunakan dan melihat penjelasan-penjelasan dari Smart Card yang lain.

\section{Uji Coba Pemakaian/ Skala Besar}

Uji coba pemakaian/ skala besar peneliti menggunakan gabungan sampel yaitu: 9 mahasiswa angkatan 2016 yang pernah melalui mata kuliah Metodik Didaktik Bola Basket II dan 25 mahasiswa angkatan 2017 yang sedang mengampu mata kuliah Metodik Didaktik Bola Basket II. Sama halnya dengan uji coba skala kecil, pada uji coba skala besar mahasiswa dikelompokan yang tiap-tiap kelompok berjumlah 4-5 orang. Mahasiswa diberikan waktu kurang lebih 10 menit untuk melihat Smart Card Perwasitan Bola Basket sekaligus berdiskusi terkait Smart Card Perwasitan Bola Basket. Setelah mahasiswa melihat bentuk dari Smart Card Perwasitan Bola Basket selanjutnya peneliti mengarahkan untuk melihat satu-persatu sesuai instruksi peneliti, mahasiswa dapat bebas untuk bertanya. Peneliti memberikan instruksi kartu-kartu mana saja yang terjadi ketika pertandingan berlangsung.

Pada kesempatan ini mahasiswa dapat mempraktikkan langsung hasil dari diskusi terkait dengan Smart Card Perwasitan Bola Basket. Mahasiswa dapat memberikan respon terkait dengan Smart Card Perwasitan Bola Basket melalui kuesioner yang sudah disediakan oleh peneliti. Alur dari uji coba skala besar sama halnya dengan uji coba skala kecil yaitu nilai yang diperoleh dijadikan pedoman untuk direvisi yang dikonsultasikan oleh para ahli. Data yang diperoleh dalam uji coba skala besar berupa skor dan saran. Untuk skala besar diperoleh skor sebesar 2989 dari skor maksimal 3400, kemudian dikonversikan sebagai berikut:

$$
\begin{array}{ll}
\mathrm{P}= & \frac{\text { Jumlah skor yang diperoleh }}{\text { jumlah skor maksimal }} \times 100 \% \\
\mathrm{P}= & \frac{2989}{3400} \times 100 \% \\
\mathrm{P}= & 87,91 \%
\end{array}
$$

Hasil yang didapatkan dari uji coba skala besar sebesar $87,91 \%$ dengan kategori sangat baik. 


\section{Revisi Produk}

Revisi prodak untuk tahap ini, berdasarkan telaah dari ahli maka disimpulkan tidak ada revisi produk setelah dikonsultasikan oleh para ahli.

\section{Produksi Masal}

Produksi masal adalah penggandaan produk dalam hal ini adalah Smart Card Perwasitan Bola Basket yang mana Smart Card ini akan digunakan oleh mahasiswa Pendidikan Jasmani Universitas Jenderal Soedirman yang mengambil Mata Kuliah Bola Basket II. Pada saat uji coba skala kecil dan uji coba skala besar peneliti mengamati beberapa hal yang dapat mendukung terkait dengan penilaian produk Smart Card Perwasitan Bola Basket. Hasil pengamatan peneliti dapat dilihat pada tabel 11 berikut:

Tabel 11 Hasil Pengamatan Uji Coba Produk

\begin{tabular}{|c|c|c|c|c|}
\hline \multirow[t]{2}{*}{ No } & \multicolumn{2}{|l|}{ Uji Coba Skala Kecil } & \multicolumn{2}{|l|}{ Uji Coba Skala Besar } \\
\hline & Hal yang diamati & Keterangan & Hal yang diamati & Keterangan \\
\hline 1 & $\begin{array}{l}\text { Banyaknya pertanyaan } \\
\text { yang diajukan oleh } \\
\text { mahasiswa. }\end{array}$ & $\begin{array}{l}\text { Hal ini berpotensi } \\
\text { untuk } \\
\text { meningkatkan } \\
\text { pengetahuan } \\
\text { pada saat peneliti } \\
\text { terkait dengan } \\
\text { perwasitan bola } \\
\text { basket. }\end{array}$ & $\begin{array}{l}\text { Mahasiswa saling } \\
\text { berinteraksi satu sama } \\
\text { lain, menghormati } \\
\text { teman yang sedang } \\
\text { mempraktikkan sinyal } \\
\text { perwasitan bola basket } \\
\text { dan memberikan } \\
\text { masukan satu sama lain } \\
\text { jika ada kekeliruan } \\
\text { dalam mempraktikkan } \\
\text { sinyal perwasitan. }\end{array}$ & $\begin{array}{l}\text { Secara tidak } \\
\text { langsung } \\
\text { penelitian ini } \\
\text { melatih afektif } \\
\text { mahasiswa. }\end{array}$ \\
\hline 2 & $\begin{array}{l}\text { Keinginan mahasiswa } \\
\text { untuk mendapatkan } \\
\text { Smart Card dengan } \\
\text { formasi: satu Smart } \\
\text { Card digunakan oleh } \\
\text { satu mahasiswa. }\end{array}$ & $\begin{array}{lr}\text { Koreksi } & \text { untuk } \\
\text { peneliti } & \text { terkait } \\
\text { dengan jumlah } & \text { Smart Card yang } \\
\text { dicetak. }\end{array}$ & $\begin{array}{l}\text { Banyaknya mahasiswa } \\
\text { yang } \\
\text { mempraktikkan secara } \\
\text { langsung setelah } \\
\text { menggunakan Smart } \\
\text { Card Perwasitan bola } \\
\text { basket. }\end{array}$ & $\begin{array}{l}\text { Hal ini } \\
\text { menunjukkan } \\
\text { rasa ingin } \\
\text { mencoba pada } \\
\text { mahasiswa. }\end{array}$ \\
\hline 3 & $\begin{array}{l}\text { Tingginya antusias } \\
\text { mahasiswa pada saat } \\
\text { penyampaian produk } \\
\text { Smart Card. }\end{array}$ & $\begin{array}{l}\text { Penyampaian } \\
\text { Smart Card tidak } \\
\text { membosankan. }\end{array}$ & $\begin{array}{l}\text { Mahasiswa mampu } \\
\text { membaca tulisan pada } \\
\text { Smart Card. }\end{array}$ & $\begin{array}{l}\text { Ukuran Smart } \\
\text { Card telah sesuai } \\
\text { untuk mahasiswa. }\end{array}$ \\
\hline
\end{tabular}


Tantie Rafni Permatasari, Ayu Rizky Febriani, Ajeng Dian Purnamasari, Indra Jati Kusuma, Rifqi Festiawan | Pengembangan Media Pembelajaran Smart Card Perwasitan Bola Basket

Dari penjabaran di atas dapat disimpulkan bahwa hasil dari Pengembangan media pembelajaran Smart Card Perwasitan Bola Basket dinyatakan sangat layak untuk dipergunakan dengan tingkat kelayakan $82,61 \%$. Tingkat kelayakan tersebut merupakan gabungan dari nilai yang diperoleh baik penilaian dari para ahli maupun pada uji coba skala kecil dan skala besar.

Dari beberapa pernyataan yang dibuat oleh mahasiswa menyatakan Smart Card sendiri terbukti dapat mengubah suasana belajar lebih menyenangkan, meningkatkan antusias dari mahasiswa dan tentunya dapat menarik perhatian mahasiswa. Smart Card sendiri dinyatakan media pembelajaran yang sangat efektif untuk digunakan dalam ranah pembelajaran dalam hal ini adalah materi pembelajaran perwasitan bola basket (Oktaviani et al., 2019).

\section{PEMBAHASAN}

Penelitian terhadap produk Smart Card Perwasitan Bola Basket yang telah selesai dikembangkan mendapatkan hasil yang positif. Materi perwasitan yang dikembangkan memperoleh nilai sangat baik setelah ditelaah oleh ahli materi, bahsa dan media yang digunakan juga memperoleh nilai yang baik berdasarkan hasil penilaian ahli bahasa dan ahli media pembelajaran. Hasil penilaian dari mahasiswa juga menunjukan hasil yang sangat baik karena materi perwasitan bola basket cukup menarik dan mudah dipahami oleh mahasiswa.

Tingginya penilaian dari mahasiswa terkait dengan pengembangan media pembelajaran telah mendapatkan nilai yang baik sehingga model pembelajaran yang diterapkan dalam proses pembelajaran dapat memberikan dampak dalam peningkatan efektifitas proses pembelajaran olahraga permainan. Hasil penelitian terdahulu menunjukan bahwa penerapan model pembelajaran dapat memberikan solusi terhadap permasalahan pada proses pembelajaran (Faozi, Sanusi, \& Listiandi, 2019; Rahayu, Subroto, \& Budiman, 2020). Pada penelitian ini menggunakan model pembelajaran Problem Based Instruction (PBI) untuk dapat meningkatkan aktivitas belajar.

Yuslolita (2019) menyatakan bahwa Pembelajaran Problem Based Instruction (PBI) dengan media kartu menekankan terbangunnya pemahaman sendiri secara efektif, kreatif, dan produktif berdasarkan pengetahuan terdahulu. Lebih lanjut Yuslolita (2019) menyatakan bahwa dengan media kartu pada proses pembelajaran IPA dapat 
meningkatkan aktivitas belajar siswa. Untuk persentase sendiri pada tahap I yaitu $62,50 \%$ dan tahap II mencapai $81,41 \%$. Untuk penelitian ini mendapatkan hasil yaitu, tahap I atau uji coba skala kecil memperoleh nilai $85,15 \%$ dan untuk tahap II atau uji coba skala besar memperoleh nilai $87,91 \%$.

Hasil penelitian ini menunjukkan bahwa Smart Card Perwasitan Bola Basket dapat diterapkan sebagai media belajar perwasitan bola basket untuk mahasiswa Pendidikan Jasmani Universitas Jenderal Soedirman dengan hasil persentase $84.61 \%$ yang dikategorikan sangat baik. Berdasarkan hasil penelitian maka, pengembangan dan modifikasi pembelajran perlu dilakukan untuk meningkatkan proses keberhasilan mengajar dan meningkatkan hasil belajar, khusunya pada mata kuliah bola basket dengan konsentrasi pertandingan dan perwasitan pada mahasiswa.

Penelitian ini memiliki beberapa keterbatasan yang dapat dikembangkan pada penlitian selanjutnya. Pengembangan media yang dilakukan hanya berfokus pada proses pertandingan dan perwasitan bola basket, belum mengkaji tentang penegmbangan media pembelajaran untuk teknik dasar dan teknik bermain bola basket. Sampel penelitian yang digunakan juga hanya terbatas pada mahasiswa olahraga, sehingga perlu diuji dan dikembangkan pada tingkat pendidikan yang lain, seperti siswa SMP maupun SMA, sehingga kebermaknaan dari pengembangan Smart Card dapat lebih fektif dan bermafaat pada proses pembelajaran bola basket.

\section{SIMPULAN}

Penelitian ini menghasilkan sebuah produk yang diberi nama "Smart Card Perwasitan Bola Basket" dengan ukuran panjang $7 \mathrm{~cm}$ dan lebar $10 \mathrm{~cm}$ dinyatakan layak untuk digunakan sebagai salah satu media pembelajaran terkait dengan materi perwasitan bola basket untuk mahasiswa Pendidikan Jasmani Universitas Jenderal Soedirman. Smart Card ini juga dapat menumbuh kembangkan rasa keingintahuan dan keaktifan mahasiswa dalam memperlajari materi perwasitan bola basket.

\section{REFERENSI}

Agustan, B., Kusmaedi, N., \& Hendrayana, Y. (2020). Modifikasi pembelajaran : hybrid sport education-invasion games competence model terhadap performa permainan bola basket Modification of learning: hybrid sport education-invasion games 
Tantie Rafni Permatasari, Ayu Rizky Febriani, Ajeng Dian Purnamasari, Indra Jati Kusuma, Rifqi

competence model on basketball game performance PENDAHULUAN Pembelaja. $6(1), 157-172$.

Budi, D. R. (2015). Pengaruh Modifikasi Permainan Vobas dan Kebugaran Jasmani terhadap Peningkatan Kerjasama Siswa dalam Pembelajaran Penjas di SMP. Thesis. Retrieved from http://repository.upi.edu/id/eprint/17605

Faozi, F., Sanusi, H., \& Listiandi, A. D. (2019). Pengaruh Model Pembelajaran Kooperatif Tipe Stad Terhadap Keterampilan Passing Bawah Dalam Permainan Bola Voli Di SMA Islam Al-Fardiyatussa'adah Citepus Palabuhanratu. Physical Activity Journal. https://doi.org/10.20884/1.paju.2019.1.1.2001

Faridah, N. (2013). penerapan media smart crad untuk meningkatkan penguasaan kosakata bahasa arab siswa kelas III MI Miftahul Huda gresik. Journal of Chemical Information and Modeling, 53(9), 1689-1699. https://doi.org/10.1017/CB09781107415324.004

Febriani, A. R., Hidayat, R., \& Budi, D. R. (2019). Referee's Signal Sebagai Media Belajar Pada Mata Kuliah Bola Basket Mahasiswa Pendidikan Jasmani Kesehatan dan Rekreasi UNSOED. Jendela Olahraga. https://doi.org/10.26877/jo.v4i2.3841

Festiawan, R., \& Arovah, N. I. (2020). Pengembangan " Buku Saku Pintar Gizi " Untuk Siswa: Alternatif Media Pembelajaran untuk Meningkatkan Pengetahuan Gizi Olahraga. Physical Activity Journal, 1(2), 188-201.

Festiawan, R., Ngadiman, N., Kusuma, I. J., Nurcahyo, P. J., \& Kusnandar, K. (2019). Pengembangan Model Pembelajaran Pendidikan Jasmani Berbasis Games, Education, and Visualisation (GEV) Untuk Meningkatkan Pengetahuan Kesehatan $\begin{array}{llll}\text { Reproduksi Remaja. Jendela Olahraga, } & 4(2), & 13 .\end{array}$ https://doi.org/10.26877/jo.v4i2.3678

FIBA. (2018). 2018 official basketball rules.

Mózo, B. S. (2017). 済無No Title No Title. Journal of Chemical Information and Modeling, 53(9), 1689-1699. https://doi.org/10.1017/CB09781107415324.004

Oktaviani, R., Sudrajat, R., \& Wijayanti, A. (2019). Keefektifan Model Pembelajaran Course Review Horay berbantu Media Kartu Pintar t erhadap Hasil Belajar IPS. 3(1), 29-34.

Rahayu, R., Subroto, T., \& Budiman, D. (2020). Implementasi Model Pembelajaran Pada Olahraga Permainan Bolatangan. Physical Activity Journal. https://doi.org/10.20884/1.paju.2020.1.2.2172

Sampurno, H. W., \& Qohhar, W. (2020). Perbandingan Gaya Mengajar Terhadap Hasil Shooting Bola Basket. Physical Activity Journal. https://doi.org/10.20884/1.paju.2020.1.2.2493

Sugiyono. (2016). metode penelitian (23rd ed.). Bandung: ALFABETA. 
Yuslolita, Y. (2019). Peningkatan Kualitas Pembelajaran IPA Melalui Model Pembelajaran Problem Based Instruction (PBI) dengan Media Kartu Pintar pada Siswa Kelas III SD Negeri 64/IV Kota Jambi Semester Genap Tahun Pelajaran 2017/2018. Jurnal IImiah Universitas Batanghari Jambi, 19(2), 334. https://doi.org/10.33087/jiubj.v19i2.652 